twice the upper limit of normal. A sesond child in this family was born in April 1975. He became positive for HBsAg in October despite prophylactic hyperimmune $\gamma$-globulin at birth.

\section{Discussion}

The impression of a strong association between the presence of $\mathrm{HBsAg}$ and actual infectivity of the blood gained from early blood transfusion studies ${ }^{3}$ was modified by failures to detect evidence of infection after exposure to such blood. ${ }^{2}{ }^{6}$ After the recognition of the Dane particle ${ }^{17}$ as the likely virus it was observed that this particle is present in only some HBsAgpositive blood and, notably, is found only rarely in apparently healthy carriers of HBsAg. ${ }^{1{ }^{1}} 19$ These findings indicated a need for a serological marker for the presence of Dane particles in HBsAg-positive blood. Serological testing for the Dane-particleassociated core antigen-antibody system ${ }^{20}$ has been technically difficult, and only recently have assays of the antibody by radioimmunoassay, complement fixation, or CIE become possible. ${ }^{21}$

The presence of anti-HBc has been thought to be a marker of viral replication and thus of infectivity. ${ }^{21}$ This antibody, however, might be present for a long time after infection ${ }^{22}$ and could therefore indicate past as well as present infection. The more recently described e antigen-antibody system is not yet characterised in detail but the antigen appears to be of low molecular weight and is not particle-bound. ${ }^{23}$ Although the origin and composition of $\mathrm{HBeAg}$ is unknown, its presence in sera rich in Dane particles led to the assumption that it might be a viral product and a marker of infectivity. ${ }^{1423}$

Our study confirmed that the healthy HBsAg carriers, although all positive for anti-HBc, did not infect their children during the four to five years. Nor was there evidence of infection in the 13 older and younger children or in the husbands studied.

The positive anti-HBc reaction in three of the children could not be correlated with any other findings. None of the two sisters and one father from the three families had any sign of infection, and the mothers and children did not differ from those in the remaining families in any other serological test. In contrast, several tests confirmed transmission of hepatitis to the children and husband of the $\mathrm{HBeAg}$-positive mother. This mother differed clinically from the remaining mothers by having a renal graft and being on immunosuppressive treatment. Biochemical tests of liver damage gave negative results, however, as they did for the other women studied, and serologically only the presence of $\mathrm{HBeAg}$ suggested her infectivity.

These preliminary studies on the importance of $\mathrm{HBeAg}$ tests are at present being extended to areas with a higher motherinfant transmission rate.

\section{References}

${ }^{1}$ British Medical fournal, 1974, 4, 427.

2 Cherubin, C E, Lancet, 1971, 1, 627.

${ }^{3}$ Goche, D J, Fournal of the American Medical Association, 1972, 219, 1165.

4 Szmuness, W, et al, New England Fournal of Medicine, 1973, 289, 1162.

${ }^{5}$ Heathcote, J, Gateau, P, and Sherlock, S, Lancet, 1974, 2, 370.

${ }^{6}$ Skinhøj, P, et al, American fournal of Diseases of Children, 1972, 123, 380

${ }^{7}$ Aziz, M A, et al, fournal of Infectious Diseases, 1973, 127, 110.

${ }^{8}$ Desmyter, J, Liu, W $\mathrm{T}$, and van den Berge, $\mathrm{H}$, Intrauterine infection. Ciba Foundation Symposium, No 10, p 101. Amsterdam, Elsevier, 1973.

9 Schweitzer, I L, et al, Gastroenterology, 1973, 65, 277.

10 Cossart, Y E, Postgraduate Medical fournal, 1974, 50, 334.

11 Skinhøj, P, et al, Acta Pathologica et Microbiologica Scandinavica, Section B, $1972,80,362$.

12 Skinh $\phi$, P. Unpublished observations.

${ }^{13}$ Skinh $\phi j$, P, and Hansen, J F, Scandinavian fournal of Clinical and Laboratory Investigation, 1973, 32, 199.

14 Magnius, L O, and Espmark, J §, Fournal of Immunology, 1972, 109, 1017

15 Nielsen, J O, Dietrichson, O, and Juhl, E, Lancet, 1974, 2, 913.

16 Desmyter, J, and Bradburne, A F, Progress on Biological Standardization. In press.

17 Dane, D S, Cameron, C H, and Briggs, M, Lancet, 1970, 1, 695.

${ }_{18}$ Nielsen, J O, Nielsen, $M \mathrm{H}$, and Elling, P, New England fournal of Medicine, 1973, 288, 484

19 Woolf, I L, et al, fournal of Clinical Pathology, 1975, 28, 260.

${ }^{20}$ Almeida, J D, Rubenstein, D, and Stott, E J, Lancet, 1971, 2, 1225.

${ }^{21}$ Hoffnagle, J H, et al, New England fournal of Medicine, 1974, 290, 1336

22 Krugman, S, et al, New England fournal of Medicine, 1974, 290, 1331.

${ }^{23}$ Magnius, L O, et al, fournal of the American Medical Association, 1975, 231, 356.

\title{
Jejunal mucosal abnormalities in patients with recurrent aphthous ulceration
}

\author{
R FERGUSON. M K BASU, P ASQUITH, W T COOKE
}

British Medical fournal, 1975, 1, 11-13

\section{Summary}

Jejunal biopsies in 33 patients with troublesome recurrent aphthous ulceration seen over one year showed eight with flat mucosa compatible with coeliac disease. All remitted completely on a gluten-free diet, both clinically and haematologically, and the aphthous ulceration did not recur. Gluten sensitivity is aetiologic-

Nutritional and Intestinal Unit, General Hospital, Birmingham

R FERGUSON, MB, MRCP, research registrar (now senior registrar, Nottingham General Hospital, Nottingham)

W T COOKE, MD, FRCP, consultant physician and head of unit

Department of Oral Pathology, University of Birmingham, Birmingham

M K BASU, BDS, FDS RCS, lecturer

Department of Experimental Pathology, University of Birmingham, Birmingham

P ASQUITH, MD, MRCP, clinical senior lecturer ally important in patients with recurrent aphthous ulceration and flat mucosa, and patients with recurrent ulceration should undergo jejunal biopsy.

\section{Introduction}

The aetiology of aphthous stomatitis is not clear and is probably diverse. ${ }^{1}$ The association between oral ulceration, diarrhoea, and weight loss has been noted for 300 years, ${ }^{2}$ and the incidence of recurrent aphthous ulceration is high in idiopathic steatorrhoea ${ }^{3}$ and coeliac disease. ${ }^{4}$ It seemed relevant, therefore, to study the jejunal mucosa of unselected patients presenting with recurrent aphthous stomatitis.

\section{Patients and methods}

The patients studied came from two sources. All patients referred by their general practitioners to the nutritional and intestinal unit (eight patients) or to one of us (MKB) at the Dental Hospital, Birmingham (25 patients), over one year with recurrent aphthous ulceration $^{56}$ were studied. To be included patients had to have had recur- 
rent ulceration, either major or minor aphthous ulcers, ${ }^{6}$ for at least six months, and they had to give their informed consent to a jejunal biopsy. Consent for this procedure was obtained at the initial interview with the patient before a detailed clinical history had been obtained or other investigations begun. Three patients had major aphthous ulceration and 30 had minor aphthous ulcers.

Symptoms-The patients were asked whether they suffered from abdominal discomfort, diarrhoea, flatulence, or lethargy. We did not attempt to define these symptoms, except diarrhoea, which was defined as the passage of three or more semi-formed motions a day regularly for three months or more.

Haematological and biochemical investigations-Venous blood was taken from all patients. The haemoglobin, serum folate, and serum $B_{12}$ were determined routinely by standard laboratory techniques. Serum total protein, albumin, and alkaline phosphatase were measured routinely by autoanalyser techniques. Serum globulin estimations were obtained by subtracting the serum albumin level from the total protein estimation.

fejunal biopsies-Jejunal biopsies were obtained from all patients using a simple suction multiple biopsy capsule. ${ }^{7}$ The jejunal mucosa, after initial orientation under a dissecting microscope, underwent routine histological processing. Histological sections were classified using the criteria of Roy-Choudhury et al. ${ }^{8}$ Cell counts were also performed-for example, the number of plasma cells and lymphocytes per $\mathrm{mm}^{2}$ of lamina propria and the number of lymphocytes per $\mathrm{mm}$ length of epithelium ${ }^{9}$ were counted.

The results were analysed using Student's $t$ test, and the $\chi^{2}$ test with Yates's correction.

\section{Results}

fejunal mucosa-Fourteen patients had villi and leaves visible on dissecting microscopy, and of these seven also had ridges. Ten further patients had leaves and ridges. One patient had leaves, ridges, and convolutions, and eight had biopsy specimens that had a flat mosaic appearance. Histologically three patients had completely normal appearances, 21 had grade I histological changes, one had grade II changes, and eight had grade III changes-that is, those consistent with coeliac disease. These eight patients ranged in age from 12 to 25 years and seven were female.

Cell counts-The results of the cell counts in the groups studied are illustrated in table I. In the lamina propria the plasma cell counts in the non-coeliac group of patients with aphthous ulcers were significantly raised compared with those of normal controls $(P<0.001)$. Counts were also significantly raised in the coeliac group of patients compared with those in both normal controls $(P<0.001)$ and the other patients with aphthous ulcers $(P<0.005)$. The counts of the coeliac group did not differ significantly from those of patients with confirmed coeliac disease. The numbers of intraepithelial lymphocytes in the non-coeliac group were raised compared with those in normal controls $(\mathrm{P}<0.05)$. The coeliac group had more of these cells than both normal controls $(P<0.001)$ and the non-coeliac group $(P<0.05)$. The numbers of epithelial lymphocytes did not differ significantly between the coeliac group and patients with confirmed coeliac disease.

Symptoms-There were no significant differences in respect of any symptoms whether or not the patient had a flat biopsy specimen (table II).

TABLE I-Mean $\left( \pm S E\right.$ ) cell counts per $\mathrm{mm}^{2}$ of lamina propria and per $\mathrm{mm}$ length of epithalium in groups of patients studied

\begin{tabular}{|c|c|c|c|c|}
\hline & \multirow{2}{*}{$\begin{array}{l}\text { Controls } \\
(n=20)\end{array}$} & \multicolumn{2}{|c|}{$\begin{array}{l}\text { Patients with aphthous } \\
\text { ulcers }\end{array}$} & \multirow{2}{*}{$\begin{array}{c}\text { Patients with } \\
\text { coeliac } \\
\text { disease on } \\
\text { normal } \\
\text { diet } \\
(n=20)\end{array}$} \\
\hline & & $\begin{array}{c}\text { Non-coeliac } \\
\text { group } \\
(\mathrm{n}=25)\end{array}$ & $\begin{array}{l}\text { Coeliac } \\
\text { group } \\
(\mathrm{n}=8)\end{array}$ & \\
\hline $\begin{array}{l}\text { Lamina propria: } \\
\text { Plasma cells. } \\
\text { Lymphocytes }\end{array}$ & $\begin{array}{c}1050 \pm 101 \\
2971 \pm 178 \\
53 \pm 5\end{array}$ & $\begin{array}{c}2064 \pm 243 \\
2560 \pm 141 \\
66 \pm 4\end{array}$ & $\begin{array}{c}7020 \pm 1198 \\
1760 \pm 404 \\
113 \pm 17\end{array}$ & $\begin{aligned} 9421 & \pm 492 \\
1251 & \pm 141 \\
133 & \pm 6\end{aligned}$ \\
\hline
\end{tabular}

Haematological and biochemical values-Both haemoglobin and serum folate levels were significantly lower in the coeliac group $(\mathrm{P}<0.001$ and $\mathrm{P}<0.0001$ respectively) compared with the noncoeliac group (tables III and IV). A significantly greater proportion of the coeliac group had abnormal haemoglobin and folate levels $\left(x^{2}=5.061\right.$ and 8.177 respectively). A similar proportion of patients in both groups had low serum $B_{12}$ levels. Only three patients, two of whom had grade III histological specimens, had a serum albumin of less than $40 \mathrm{~g} / \mathrm{l}$. A raised serum alkaline phosphatase was found in two patients, who both had grade III changes.

Effects of gluten-free diet-All eight patients in the coeliac group underwent treatment with a gluten-free diet for at least nine months. All had complete remission in symptoms, and haematological and biochemical values were restored to normal. In all the aphthous ulcers have completely resolved and have not recurred.

TABLE II-Symptoms occurring in both groups of patients with aphthous ulceration

\begin{tabular}{|c|c|c|c|c|c|}
\hline & \multirow{2}{*}{$\begin{array}{c}\text { No of } \\
\text { patients }\end{array}$} & \multicolumn{4}{|c|}{ No $\left(\begin{array}{l}0 \\
0\end{array}\right)$ with symptoms } \\
\hline & & $\begin{array}{l}\text { Adbominal } \\
\text { discomfort }\end{array}$ & Diarrhoea & Flatulence & Lethargy \\
\hline $\begin{array}{l}\text { Coeliac group . } \\
\text { Non-coeliac group }\end{array}$ & $\begin{array}{r}8 \\
25\end{array}$ & $\begin{array}{l}3(37 \cdot 5) \\
15(60)\end{array}$ & $\begin{array}{l}5(62 \cdot 5) \\
11(44)\end{array}$ & $\begin{array}{l}3(37 \cdot 5) \\
11(44)\end{array}$ & $\begin{array}{l}7(87 \cdot 5) \\
12(48)\end{array}$ \\
\hline
\end{tabular}

TABLE IV-Mean $( \pm S E)$ haematological results in both groups

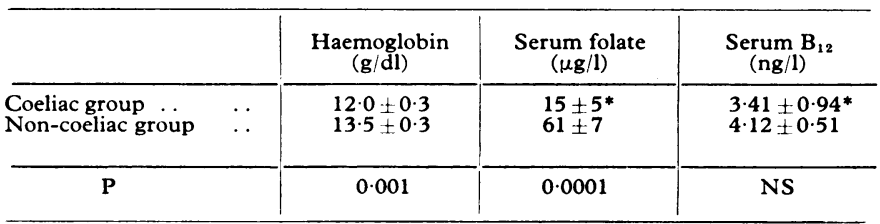

*Serum folate and $B_{12}$ were measured in only 7 patients in the coeliac group.

\section{Discussion}

The finding of so many patients with flat mucosa was unexpected, as was the dramatic disappearance of aphthous ulceration on withdrawing gluten from their diets. Only one patient had been suspected of having coeliac disease (when a child 30 years earlier), and none had been referred for consultation with this diagnosis in mind. No help in predicting the presence of a flat mucosa was gained from the associated symptoms. While it is apparent from this and the study by Wray et al ${ }^{10}$ that patients with recurrent aphthous ulceration should undergo routine haematological screening, the response encountered did not depend on the concurrent administration of haematinics such as folic acid, as others have confirmed. ${ }^{1011}$

Gluten sensitivity was clearly an aetiological factor in the recurrent aphthous ulceration in those with flat mucosa. Increased plasma cell counts and decreased lymphocyte counts in the lamina propria of the same order as those seen in our patients occur in patients with coeliac disease on a normal diet, reverting towards normal after gluten withdrawal. ${ }^{912}$ Plasma cells found in the jejunal mucosa represent a response to antigen in the lumen of the gut ${ }^{13}{ }^{14}$-in these cases gluten. Other patients who did not have a flat jejunal mucosa might also have been exhibiting some form of immunological reaction to a dietary factor such as gluten since similar but less pronounced changes to those seen in patients with coeliac disease on a normal diet were noted in the non-coeliac group. Hence dietary factors cannot be ignored as a possible aetiological factor in the jejunal mucosal abnormalities of this group, and it is pertinent that

TABLE III-Numbers of patients in each group with abnormal haematological and biochemical values

\begin{tabular}{|c|c|c|c|c|c|c|c|c|c|c|}
\hline & & & & $\begin{array}{c}\text { No of } \\
\text { patients }\end{array}$ & $\begin{array}{l}\text { Haemoglobin } \\
<13 \mathrm{~g} / \mathrm{dl}\end{array}$ & $\begin{array}{l}\text { Serum folate } \\
<3 \mu \mathrm{g} / 1\end{array}$ & $\begin{array}{l}\text { Serum } B_{12} \\
<150 \mathrm{ng} / 1\end{array}$ & $\underset{<40 \mathrm{~g} / \mathrm{l}}{\text { Serum albumin }}$ & $\underset{>35 \mathrm{~g} / 1}{\stackrel{\text { Serum globulin }}{ }}$ & $\begin{array}{c}\text { Serum alkaline } \\
\text { phosphatase } \\
>\text { BKA units }\end{array}$ \\
\hline $\begin{array}{l}\text { Coeliac group } \\
\text { Non-coeliac group }\end{array}$ & 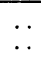 & $\begin{array}{l}\ldots \\
\cdots\end{array}$ & $\begin{array}{l}\cdots \\
\cdots\end{array}$ & $\begin{array}{r}8 \\
25\end{array}$ & $\begin{array}{l}7 \\
8\end{array}$ & $\begin{array}{l}6 \\
3\end{array}$ & 1 & $\begin{array}{l}2 \\
1\end{array}$ & $\begin{array}{l}0 \\
1\end{array}$ & $\begin{array}{l}2 \\
0\end{array}$ \\
\hline
\end{tabular}


others ${ }^{15}$ have found a high incidence of circulating antibodies to cows' milk, protein, and gluten in patients with aphthous ulcers. Many of these patients, however, did not have recurrent aphthous ulceration according to the criteria we used. ${ }^{6}$

If those patients with a flat mucosa, with their dramatic clinical response to gluten withdrawal, are accepted as having coeliac disease, ${ }^{16}$ then there are probably many people with undiagnosed coeliac disease. Our results also indicate the importance of performing jejunal biopsies in patients referred to general medical or dental outpatient departments with recurrent aphthous ulceration.

\section{References}

${ }^{1}$ British Medical fournal, 1974, 2, 757

2 Ketelaer, V, (1669), quoted in Classic Descriptions of Disease, Major, R H, 2nd edn, p 657. Springfield, Thomas, 1939.
${ }^{3}$ Cooke, W T, Peeney, A L P, and Hawkins, C F, Quarterly fournal of Medicine, 1953, 22, 59.

${ }^{4}$ Barry, R E, Baker, P, and Read, A E, Clinics in Gastroenterology, 1974, 3, 55.

5 Truelove, S C, and Morris-Owen, R M, British Medical fournal, 1958, 1, 603.

${ }^{6}$ Lehner, T D, Proceedings of the Royal Society of Medicine, 1968, 61, 515.

7 Roy-Choudhury, D C, Nicholson, G N, and Cooke, W T, Lancet, 1974, 2, 185.

8 Roy-Choudhury, D C, et al, Scandinavian fournal of Gastroenterology, 1966, 1, 57.

${ }^{9}$ Holmes, G K T, et al., Gut, 1974, 15, 278.

10 Wray, D, et al, British Medical fournal, 1975, 2, 410.

11 Sircus, W, Church, R, and Kelleher, J, Quarterly fournal of Medicine, 1957, 26, 235.

12 Ferguson, R, Asquith, P, and Cooke, W T, Gut, 1974, 15, 458

13 Crabbe, P A, et al, Internal Archives of Allergy, 1968, 34, 362.

14 Kenworthy, R, fournal of Comparative Pathology, 1970, 80, 53.

15 Taylor, K B, Truelove, S C, and Wright, R, Gastroenterology, 1964, 46, 99

${ }^{16}$ Cooke, W T, and Asquith, P, Clinics in Gastroenterology, 1974, 3, 3.

\title{
Logical approach to lignocaine therapy
}

\author{
C APS, J A BELL, B S JENKINS, P A POOLE-WILSON, FELICITY REYNOLDS
}

British Medical fournal, 1975, 1, 13-15

\section{Summary}

Plasma lignocaine concentrations were measured during and after lignocaine infusions administered for suppressing ventricular dysrhythmias. Twenty-four patients with a primary diagnosis of acute myocardial infarction without gross circulatory disturbance received, after a bolus of lignocaine, either $4 \mathrm{mg} / \mathrm{min}$ for 30 minutes, $2 \mathrm{mg} / \mathrm{min}$ for two hours, then $1 \mathrm{mg} / \mathrm{min}$ thereafter or $1 \mathrm{mg} / \mathrm{min}$ throughout. The higher dose regimen produced continuous therapeutic levels of lignocaine, which were achieved only after four hours by the lower dose. On the other hand, in patients who had undergone cardiac surgery and who had circulatory and hepatic dysfunction the lower dose regimen achieved therapeutic levels early. The plasma half life was longer in the surgical group $(P<0.02)$. The higher initial infusion rate is recommended for patients with acute myocardial infarction without gross circulatory impairment.

\section{Introduction}

Lignocaine has been widely used since the 1950 s to control ventricular dysrhythmias associated with myocardial infarction and cardiac surgery, ${ }^{1}$ yet its value remains controversial. ${ }^{2}$ In some studies it has not suppressed ventricular extrasystoles,,$^{3-6}$ whereas in others ventricular extrasystoles may have been inhibited but ventricular fibrillation and mortality have not been reduced. ${ }^{7-9}$ More recent studies have, however, shown a reduction in mortality and the incidence of ventricular fibrilla-

St Thomas's Hospital and Medical School, London SE1

C APS, FFA RCS, senior registrar, department of anaesthetics, and research fellow, department of pharmacology

J A BELL, MRCP, senior medical registrar

B S JENKINS, MRCP, senior lecturer in clinical physiology and honorary consultant physician

P A POOLE-WILSON, MD, MRCP, lecturer, department of medicine

FELICITY REYNOLDS, MD, FFA RCS, lecturer, department of pharmacology tion in association with prophylactic lignocaine administration. ${ }^{10-12}$

One explanation of these inconsistent results is that the various rates of lignocaine administration did not maintain plasma concentrations within the therapeutic range. The most widely advocated regimen is an intravenous bolus of lignocaine of $1-2 \mathrm{mg} / \mathrm{kg}$ followed, if necessary, by an infusion at a steady rate of 1-4 mg/min. ${ }^{1{ }^{13-15}} \mathrm{~A}$ constant rate of infusion of a basic, lipid-soluble drug such as lignocaine, which is concentrated in tissues, ${ }^{16}$ will produce a slow rise in plasma concentration and a plateau only after several hours. ${ }^{17} \mathrm{~A}$ high-dose constant infusion rate may therefore achieve early therapeutic levels but eventually lead to toxicity, whereas low infusion rates may take many hours to produce therapeutic levels. We devised a regimen that we hoped would quickly give an adequate plasma concentration while not eventually leading to toxicity. This regimen-a high initial dose declining in steps-is the opposite of current constant infusion regimens which need increasing when a therapeutic effect is not achieved. We compared the resulting plasma concentrations with those produced by a standard $1 \mathrm{mg} / \mathrm{min}$ regimen. We also measured the plasma disappearance of lignocaine after the end of the infusion in patients with varying cardiac and hepatic function.

\section{Patients and methods}

Plasma lignocaine concentrations were measured in 36 patients who were admitted to the intensive therapy unit with presumed acute myocardial infarction (AMI) or after cardiothoracic surgery and who were given lignocaine by infusion for control of ventricular dysrhythmias. All patients received an initial bolus of 75-100 mg intravenously followed within a few minutes by an infusion into an internal jugular vein using a constant rate infusion pump. The electrocardiogram was monitored continuously with an oscilloscope.

Comparison of lignocaine infusions in myocardial infarction-Twentyfour patients with a presumptive diagnosis of AMI and with no clinical evidence of gross cardiac failure, reduced cardiac output (as judged by blood pressure, pulse volume, peripheral perfusion, urine output, etc), or impaired liver function were randomly allocated to one of two treatment groups. Group A received $4 \mathrm{mg} / \mathrm{min}$ for $30 \mathrm{~min}$, $2 \mathrm{mg} / \mathrm{min}$ for two hours, then $1 \mathrm{mg} / \mathrm{min}$ thereafter (the 4-2-1 regimen). Group B received $1 \mathrm{mg} / \mathrm{min}$ throughout. Infusions were continued for as long as was indicated clinically. If a further bolus injection of lignocaine was required because of dysrhythmias sampling was discontinued.

Venous blood samples were taken for lignocaine estimation imme- 